УДК 343.2

DOI https://doi.org/10.32782/2524-0374/2021-4/172

\title{
CIRCUMSTANCES THAT EXCLUDE THE CRIMINAL ILLEGALITY OF THE ACT UNDER THE CRIMINAL CODES OF UKRAINE AND SOME FOREIGN COUNTRIES
}

\section{ОБСТАВИНИ, ЩО ВИКЛЮЧАЮТЬ ПРОТИПРАВНІСТЬ ПОВЕДІНКИ ЗГІДНО КРИМІНАЛЬНОГО ЗАКОНОДАВСТВА УКРАЇНИ ТА ІНОЗЕМНИХ ДЕРЖАВ}

\author{
Soloviova Alina, doctor of law, \\ Professor of Criminal Law, criminology, civil and commercial law, \\ Vice-Rector for International Cooperation, \\ National Academy of Management
}

\begin{abstract}
У статті аналізується кримінальне законодавство країн Східної Європи. Автором встановлено, що в законодавстві країн Східної Європи закріплений певний перелік обставин, за наявності яких діяння не мало б ознак злочинної протиправності, суспільної небезпечності, провини або покарання. Робиться висновок про те, що в кожній країні Східної Європи ці обставини мають різні назви і певні відмінності в змісті.

Кримінальне законодавство всіх країн Східної Європи закріплює певний перелік обставин, за наявності яких дія не мала б ознак кримінальної протиправності, суспільної небезпеки, вини чи покарання. Найпоширенішими серед них є самооборона та крайня необхідність. Вони отримали визнання у кримінальному праві майже у всіх країнах Східної Європи.

Обставини, що виключають протиправність поведінки, характеризуються рядом спільних рис.

1) Вчинки - це свідомі та вольові дії особи у формі дії чи бездіяльності. Водночас такі вчинки можуть бути виправданими лише в тому випадку, якщо вони спричинені винятковими обставинами, тобто певними причинами, які виправдовують необхідність таких дій.

2) Подібність фрактичних, видимих об'єктивних ознак поведінки та злочину. Наприклад, позбавлення життя через необхідну оборону має ті ж зовнішні ознаки вбивства.

3) Дії не мають кримінального характеру; вони характеризуються правомірністю заподіяння шкоди. Така легітимність ґрунтується або на суб'єктивному праві, на авторитеті тощо.

Ключові слова: кримінальне право, обставини, що виключають протиправність діяння, злочин, кримінальне правопорушення, країни Східної Європи.

The article analyses the criminal legislation of the countries of Eastern Europe. The author found that the legislation of the countries of Eastern Europe enshrines a certain list of circumstances, in the presence of which the act would not have signs of criminal wrongfulness, public danger, guilt, or punishment. It is concluded that in each country of Eastern Europe, these circumstances have different names and certain differences in content.

The criminal legislation of all countries of Eastern Europe enshrines a certain list of circumstances, in the presence of which an act would not have signs of criminal unlawfulness, public danger, guilt, or punishment. Since in each country, these circumstances have different names. Those circumstances provided in the Codes of Eastern European countries significantly differ. The most common among them are self-defense and extreme necessity. They have gained recognition in the criminal law in almost all countries of Eastern Europe.

The circumstances precluding wrongfulness of conduct are characterized by a number of common features.

1) Deeds are conscious and volitional actions of a person in the form of action or inaction. At the same time, such deeds can only be justified if they are caused by exceptional circumstances, i.e. certain reasons, which justify the need for such actions.

2) The second sign is the similarity of the actual, visible objective signs of conduct and a crime. For example, deprivation of life due to the necessary defence has the same external signs of a murder.

3) The third sign is that deeds don't have criminal nature; they are characterized by the legitimacy of harm. Such legitimacy is based either on subjective law, on authority, etc.

Key words: criminal law, circumstances precluding wrongfulness of conduct, crime, criminal offense, the countries of Eastern Europe.
\end{abstract}

The criminal legislation of all countries of Eastern Europe enshrines a certain list of circumstances, in the presence of which an act would not have signs of criminal unlawfulness, public danger, guilt or punishment. Since in each country these circumstances have different names, hereinafter we will define them as "circumstances precluding wrongfulness of conduct".

The circumstances precluding wrongfulness of conduct are characterized by a number of common features.

1) Deeds are conscious and volitional actions of a person in the form of action or inaction. At the same time, such deeds can only be justified if they are caused by exceptional circumstances, i.e. certain reasons, which justify the need for such actions.

2) The second sign is the similarity of the actual, visible objective signs of conduct and a crime. For example, deprivation of life due to the necessary defence has the same external signs of a murder.

3 ) The third sign is that deeds don't have criminal nature; they are characterized by the legitimacy of harm. Such legitimacy is based either on subjective law, on authority, etc.

According to the Criminal Code of Russian Federation, the circumstances that exclude the crime of an act are justifiable defence; the infliction of harm on a detained person who has committed a crime, extreme necessity, physical or mental coercion, justified risk, and execution of order or instruction.
The Republic of Belarus has a different approach. It mentions necessary defence, the infliction of harm on a detained person who has committed a crime, extreme necessity, mistake in the presence of circumstances precluding the criminal act, staying among accomplices of a crime on a special assignment, justified risk, and execution of an order or instruction.

According to the Criminal Code of Ukraine, the circumstances precluding wrongfulness of conduct include necessary defence, misread defence, apprehension of an offender, extreme necessity, physical or mental coercion, obeying an order or command, an act involving risk, undertaking a special mission to prevent or uncover criminal activities of an organized group or criminal organization.

The Criminal Code of the Slovak republic defines extreme necessity, necessary self-defence, authorized use of a weapon, permissible risk, exercising rights and performing duties, consent of the injured party, acting as an agent as circumstances excluding unlawfulness of an act.

The Criminal Code of Poland enshrines necessary defence, averting an immediate danger, conducting a cognitive, medical, technical or economic experiment, an act while being in error as to a circumstance constituting a feature of a prohibited act, justified but mistaken conviction that a circumstance has occurred which excludes unlawfulness or guilt, justifiably 
unaware of its unlawfulness, incapable of recognising its significance or controlling his conduct because of a mental disease, mental deficiency or other mental disturbance.

Those circumstances provided in the Codes of Eastern European countries significantly differ. The most common among them are self-defence and extreme necessity. They have gained recognition in the criminal law in almost all countries of Eastern Europe.

Necessary defence, as a circumstance precluding wrongfulness of conduct, is the lawful behaviour of a person resorting to the protection of interests by causing harm to the offender.

"The foundations of the right to necessary defence lie in the natural, inalienable right of self-defence against any danger. No matter where it comes from... Since the evil or offences committed by someone who protects himself, it is the exercise of a right that everyone understands ... thus, this protection cannot be punished... " (Kistyakivskyy, 1891)

According to the Criminal Code of Ukraine, the necessary defence shall mean actions taken to defend the legally protected rights and interests of the defending person or another person, and also public interests and interests of the state, against a socially dangerous trespass, by inflicting such harm upon the trespasser as is necessary and sufficient in a given situation to immediately avert or stop the trespass, provided the limits of the necessary defence are not exceeded.

Despite the apparent simplicity, the institution of necessary defence is one of the most difficult in its practical application, which is explained by the endless variety of real situations with all their nuances. Therefore, it is not surprising that the vast majority of the rules on necessary defence are not established by the legislator, but by judicial precedents or judicial practice.

In addition to the provisions of the criminal law, it is necessary to take into account clarifications of judicial practice in each specific situation. For example, paragraph 10 of the Decree of the Plenum of the Supreme Court of the Russian Federation of September 27, 2012, No. 19 "On the application by the courts of the legislation on necessary defence and harm during the apprehension of the person who committed the crime" states that when protecting agains a socially dangerous encroachment involving violence dangerous to the life of the defender or another person, or a threat of such violence (part 1 of article 37 of the Criminal Code of the Russian Federation), the defending person has the right to inflict harm on the infringing person.

The legislaton in most countries of Eastern Europe very broadly defines the acceptable object of protection against encroachment with the necessary defence. It is most widely formulated in the post-soviet countries, according to the Criminal Code of which the necessary defence is allowed when protecting the life, health and rights of the defender or other persons, the interests of the state or society from socially dangerous encroachment.

The conditions of lawfulness of defence relate not only to the nature of the assault, but also to some characteristics of the defender, although not all states contain indications of this in the criminal law.

The Criminal Code of Belarus, Latvia, Lithuania, Russia, Ukraine, directly indicate that this right belongs to all persons, regardless of the opportunity to avoid encroachment or to seek help from other persons or authorities.

One of the conditions for the legitimacy of defence is its conformity with the nature of the encroachment.

Based on the principle of proportionality, the legislation of all countries of of Eastern Europe provides liability for exceeding the limits of necessary defence. As a general rule, this liability is mitigated. However, sometimes the legislation allows a complete waiver of punishment. Thus, according to the Criminal Code of Poland, in the event that the limits of necessary defence have been exceeded, in particular when the perpetrator has used a means of defence disproportionate to the danger of the attack, the court may apply extraordinary mitigation of the penalty and even renounce its imposition (\&2 Article 25)

Some Eastern European countries provide a clear definition of exceeding the limits of necessary defence in their Criminal Codes (Bulgaria, Latvia, Russia). The most common definition is a clear discrepancy between the actions of the defending character and the degree of public danger of encroachment

Some countries include additional criteria to establish the fact of exceeding the limits of the necessary, such as a special form of guilt, as well as an objective sign in the form of serious negative consequences of harm.

Special rules on liability for harm during the apprehension of an offender are provided for in the Criminal Code of Russia, Belarus, Bulgaria, Ukraine, Latvia, and Lithuania.

According to the Criminal Code of Ukraine, any actions of the victim or other persons immediately following a trespass, the apprehending of the offender and bringing him or her to appropriate public authorities and were not in excess of what was necessary for such apprehension, are not deemed to be criminal (Article 38).

The time period, within which lawful harm to an offender is possible, was defined in a different way. For example, the Criminal Codes of Bulgaria, Moldova, and Russia, do not contain any explanations related to the time period.

In Russian criminal law, the prevailing view is that the specified period begins from the moment of preparation for the crime, or the start of the attempted crime, and ends with the expiration of the statute of limitations or limitation of the sentence (if the offender was convicted, but somehow evaded from serving a sentence). In Russian criminal law, the prevailing view is that the specified period starts from the moment of preparation for the crime, or the start of the attempted crime, and ends with the expiration of the statute of limitations for the criminal liability.

As noted in the scientific literature, the institution of extreme necessity is one of the oldest measures of criminal law. Decisions on the admissibility of harm to protect a more valuable good were already known to Roman law.

According to the Criminal Code of Russian Federation, the harming of legally-protected interests in a state of extreme necessity, that is, for the purpose of removing a direct danger to a person or his rights, to the rights of other persons or to the legally-protected interests of the society or the State, shall not be deemed to be a crime if this danger could not be removed by other means and if there was no exceeding the limits of extreme necessity.

Hegel expressed very precisely the nature of extreme necessity in his classic work "Philosophy of Law":

"If for example it is only by stealing bread that the wolf can be kept from the door, the action is of course an encroachment on someone's property, but it would be wrong to treat this action as an ordinary theft. To refuse to allow a man in jeopardy of his life to take such steps for self-preservation would be to stigmatize him as without rights, and since he would be deprived of his life, his freedom would be annulled altogether. Many diverse details have a bearing on the preservation of life, and when we have our eyes on the future, we have to engage ourselves in these details."

The extreme necessity is always a clash of two protected interests, in which the preservation of one of them is possible only by harming the other. For example, the cashier gives the proceeds to armed criminals. The state of emergency is also possible when two responsibilities collide.

The reasons that create danger (while applying extreme necessity) may be elemental forces of nature (floods, earthquakes, hurricanes, fires, snowdrifts, etc.); actions of animals if they attack not at the instigation of a person; physiological processes in the human body (hunger, thirst, disease, etc.); unlawful behaviour of a person (for example, careless handling of fire), etc. 
Some countries, when determining the limits of emergency, do not proceed from the size of the harm inflicted, but from the ratio of the value of the protected goods (interests) and those that are harmed. According to the Criminal Code of Poland, whoever acts with the purpose of averting an immediate danger threatening any interest protected by law, if the danger cannot otherwise be avoided but the interest sacrificed has a lower value than that of the interest rescued, shall be deemed to have not committed an offence. (Article 26).

The legislation sometimes attributed to the conditions of lawfulness of actions by the absence of the cause of harm the obligation to be at risk or to show self-sacrifice in certain situations.

This feature is mentioned in the Criminal Codes of Lithuania and Bulgaria.

The Criminal Code of Lithuania claims:

"A person may not justify a failure to perform a duty by invoking the provisions of immediate necessity, where he is under the obligation to act under the conditions of an increased degree of danger according to his profession, the position held or due to other circumstances" (Article 31).

The Criminal Code of Bulgaria has a different approach "an act shall be considered not dangerous to society where committed by a person in situation of emergency - in order to save state or public interests, as well as personal or property rights belonging to him or to others, from immediate danger which the acting person could not possibly avert in another way, provided the damages caused by the act are less significan than those averted" (Article 13).

According to the Criminal Code of Poland, the provisions of $\S 2$ shall not be applied when the perpetrator sacrifices an interest which he has a special duty to protect even by exposing himself to personal danger (Article 26, \&4).

To qualify the situation above we need to analyse the misread defence as a circumstance that precluding wrongfulness.

The main difference between misread defence and other circumstances that exclude the crime of an act is the subjective side, namely in the absence of guilt of the person. For example, a person harms another person, making a mistake regarding the reality of a socially dangerous attack and believing that it protects the rights and interests protected by law.

The misread defence shall mean actions resulting in a harm caused in the absence of any real socially dangerous trespass where the person, who misinterpreted actions of the victim's, only mistakenly presumed the reality of such trespass. (The Criminal Code of Ukraine, Article 37).

The Criminal Code of Poland mentions whoever commits an offence in the justified but mistaken conviction that a circumstance has occurred, which constitutes a feature of a prohibited act carrying a less severe penalty, shall be subject to criminal liability under the provision regarding the circumstance warranting this lesser liability (Article 28).

Despite the fact that the defence is imaginary, the person's defence is real, and therefore, in order to solve the legal assessment of misread defence, it is necessary to clearly understand the main characteristic signs of this circumstance.

The first feature is the absence of a socially dangerous act. That is, the harm is inflicted on the person that did not commit any illegal, criminal act but, under certain conditions, the person defends himself and incorrectly assesses the actions of the victim. In this case, the harm is caused to a person by coincidence.

The second feature is a false assumption. A person mistakenly perceived the behaviour of another person as a real criminal assault. In other words, due to the uncertainty of the situation, the conditions for necessary defence exist only subjectively, in the mind of a person.

Obeying an order or command is also considered as a circumstance that excludes criminal liability under certain conditions.
The criminal law principles of responsibility in cases of execution of the order were formulated in international criminal law during the Nuremberg International Military. In this process, the defence argued that the defendants committed the relevant acts either by order of their superior or by order of their government. In accordance with this, they allegedly could not refuse to comply with the orders binding. However, the Nuremberg Tribunal rejected this interpretation and found that the existence of a criminal order does not exempt the perpetrator from liability, although it can be considered as a reason to mitigate the punishment.

There are two different approaches to the placing of this circumstance in the system of criminal law and legislation.

In some countries, for example, in Ukraine, Russia these norms are enshrined in the General Part of Criminal Code. The other approach is to apply this circumstance only to military criminal law (Poland) or exclusively to military (Moldova) or international (Estonia) crimes.

In the vast majority of countries, legislation limits the criminal liability of a person for the execution of an order by certain conditions.

The main condition concerns the legality of the order. The Criminal Codes of Russia and Bulgaria states that a person is only liable for the execution of an obviously illegal order. According to the Criminal Code of Hungary, Lithuania, and Ukraine, a person is criminally responsible for executing a deliberately criminal order or instruction.

Physical or mental coercion is recognized as a circumstance excluding criminal liability in many countries of the world (Ukraine, the Russian Federation). This circumstance is not provided for in the Criminal Code of Belarus, Bulgaria, Latvia, Lithuania, or Estonia. However, in the Criminal Code of Belarus, and Estonia, physical and mental coercion are specifically mentioned only as a circumstance, mitigating criminal liability Under the Criminal Code of Hungary and Russia, coercion, depending on its nature, is considered as excluding liability or as a mitigating circumstance.

The Criminal Code of the Russian Federation states that the infliction of harm to legally-protected interests as a result of physical coercion shall not be a crime, if in consequence of such coercion the offender could not control his actions (inaction) (Article 40).

Despite the fact that within criminal law of many countries, physical and mental coercion are included in one article, there are significant differences between them.

Physical coercion is a physical effect on a person in order to force him to commit a socially dangerous action. Mental coercion is understood as a threat of causing any harm in order to force a person to commit a socially dangerous act.

This circumstance should be distinguished from extreme necessity.

According to the Criminal Code of Moldova, Russia, and Ukraine, if a person retained the ability to manage his actions, the issue of criminal liability should be decided according to the rules of extreme necessity. Getting back to the example, who, under the threat of immediate deprivation of his life, gives all money to criminals, despite of coercion still has an ability to control his action.

Justified risk is an action aimed at a socially useful result, which contains the likelihood of a socially dangerous outcome.

The legal norm itself clearly defines the conditions under which it is recognized that the risk was justified, and therefore, harm to the interests protected by criminal law is not considered a crime: actions related to the risk of harm were aimed at achieving a socially useful goal; this goal could not be achieved by an action (inaction) that was not associated with risk; the risk taker has taken sufficient measures to prevent possible harmful consequences.

The concept of reasonable risk, although similar, differs from the concept of extreme necessity. At reasonable risk, harm is caused when the danger has not yet occurred, 
and the possibility of its occurrence is to the actions of the person.

As an independent circumstance excluding the wrongfulness of an act, justified risk is provided for in the Criminal Code of Belarus, Bulgaria, Latvia, Lithuania, Moldova, Russia, Slovakia, and Ukraine.

In the Criminal Code of Poland, it is essentially a matter of justified risk when conducting a scientific, medical, technical or economic experiment. Whoever acts with the purpose of conducting a cognitive, medical, technical or economic experiment, shall not commit an offence when the expected benefit is of an essential cognitive, medical or economic importance, and the expectation of these benefits, their purposefulness and the way of conducting the experiment are justified according to the present state of knowledge (Article 27).

The Consent of the Injured Party as a circumstance excluding of wrongfulness of an act, is one of the most controversial issues in modern criminal law. It is not typical for countries of Eastern Europe, especially for post-Soviet states. This circumstance is enshrined in the Criminal Code of Slovak Republic.

An act, which otherwise gives rise to criminal liability, shall not be considered as a criminal offence if it was performed with the consent of the injured party and is not prejudicial to the latter's life or limb. (Section 29, the Criminal Code of Slovak Republic).

Some Eastern European countries, such as Belarus, Lithuania, and Poland, have a wide definition of justified risks in this regard. The Criminal Code of Belarus mentions that the risk is not recognized as justified if it was certainly fraught with the threat of death or serious body harm to a person who did not express consent to put his life or health in danger. (Article 39). According to part 3 of Article 35 of the Criminal Code of Lithuania and $\S 3$ of Article 27 of the Criminal Code of Poland, a scientific experiment is prohibited in the absence of free consent of the participant in the experiment, informed of the possible consequences.

The criminal laws of countries in Eastern Europe mention the exercise of legal rights, powers and duties among the circumstances that exclude wrongfulness of conduct.

However, a person should not exceed his legal authority. This rule is also formulated in the Criminal Code of Lithuania: "a person shall not be held liable under this Code for the damage caused in charge of professional duty, provided he has not exceeded the authority granted to him by laws or other legal acts" (Article 30).

A similar by its nature circumstance is enshrined in the Criminal Code of Ukraine. A compelled causing of harm to legally protected interests by a person shall not be a criminal offence, where such person was undertaking a special mission, pursuant to law, by way of participation in an organized group or criminal organization for the purpose of preventing or uncovering its criminal activities (Article 43).

Conclusion. The criminal legislation of all countries of Eastern Europe enshrines a certain list of circumstances, in the presence of which an act would not have signs of criminal unlawfulness, public danger, guilt, or punishment. Since in each country, these circumstances have different names. Those circumstances provided in the Codes of Eastern European countries significantly differ. The most common among them are self-defense and extreme necessity. They have gained recognition in the criminal law in almost all countries of Eastern Europe.

\section{REFERENCES}

1. Buzhor V.G., Guculyak V.I, Spynu I.A. Kommentarij k Ugolovnomu Kodeksu Respubliki Moldova [Comment on The Criminal Code of The Republic of Moldova]. URL: https://criminology.md/books/comentarii ug cod ob chast.pdf [in Russian].

2. Błaszczyk M., Zientara A. Prawo karne. Minirepetytorium (2020) [Criminal law] Wolters Kluwer Polska. [in Polish].

3. Criminal Code of Belarus. URL:https://cis-legislation.com/document.fwx?rgn=1977 (дата звернення - 21.02.2021).

4. Criminal Code of the Republic of Bulgaria (English version). URL: https://www.legislationline.org/download/id/8395/file/Bulgaria Criminal_Code_1968_am2017_ENG.pdf (дата звернення - 21.02.2021)

5. CCriminal Procedure Code of the Czech Republic (English version). URL: https://www.legislationline.org/download/id/6370/file/Czech\%20 Republic CC 2009 am2011 en.pdf (дата звернення - 21.02.2021).

6. Criminal Code of the Republic of Hungary English version). URL: https://www.legislationline.org/documents/section/criminal-codes/ country/25/Hungary/show (дата звернення - 21.02.2021).

7. Criminal Law of the Republic of Latvia (English version). URL: https://www.legislationline.org/download/id/8266/file/Latvia_CC_1998_ am2018_en.pdf (дата звернення - 21.02.2021).

8. CCriminal Code of Lithuania (English version). URL: https://www.legislationline.org/documents/section/criminal-codes/country/17/ Liechtenstein/show (дата звернення - 21.02.2021).

9. Criminal Code of the Republic of Moldova (English version). URL: https://www.legislationline.org/download/id/8281/file/Moldova_ CC 2002 am2018 en.pdf (дата звернення - 21.02.2021).

10. Criminal Code of the Republic Poland (English version). URL: https://www.legislationline.org/download/id/7354/file/Poland_CC_1997_ en.pdf (дата звернення - 21.02.2021).

11. Criminal Code of the Republic of Romania (English version). URL: https://www.legislationline.org/download/id/8291/file/Romania Penal\%20Code_am2017_en.pdf (дата звернення - 21.02.2021).

12. Criminal Code of the Russian Federation (English version). URL: https://www.legislationline.org/download/id/4247/file/RF_CC 1996 am03.2012_en.pdf (дата звернення - 21.02.2021).

13. Criminal Code of Ukraine (Ukrainian version). URL: https://zakon.rada.gov.ua/laws/show/2341-14 (дата звернення - 21.02.2021).

14. Penal Code of Estonia. URL: https://www.legislationline.org/download/id/8244/file/Estonia_CC_am2019_еn.pdf (дата звернення 21.02.2021).

15. Elementarnyj uchebnik obshhego ugolovnogo prava s podrobnym izlozheniem nachal russkogo ugolovnogo zakonodatel'stva: Chast' obshhaya [An elementary textbook of general criminal law with a detailed statement of the beginnings of Russian criminal law: General part] Kiev: F.A. loganson. [in Russian]

16. Soloviova A. (2019). Law: basic aspects: [textbook]. Vinnytsia.

17. Pravovyj vplyv na nepravomirnu povedinku: aktual'ni hrani: monohrafiia (2016). [Legal Impact on Misconduct: The acual aspects] za red. prof. O.V. Kozachenko, prof. Ye.L. Strel'tsova. Mykolaiv, Ilion. [in Ukrainian]. 